\title{
Water quality assessment by ecotoxicological and limnological methods in water supplies, Southeast Brazil
}

\author{
Renata A. Takenaka $\cdot$ Rosana B. Sotero-Santos • \\ Odete Rocha
}

Published online: 1 September 2006

(C) Springer Science+Business Media, LLC 2006

Erratum to: Ecotoxicology, 15, 73-82, 2006

DOI: 10.1007/s10646-005-0048-y

The publisher regrets that Fig. 4 was omitted from the original version of this article. Please see correct Fig. 4 below.

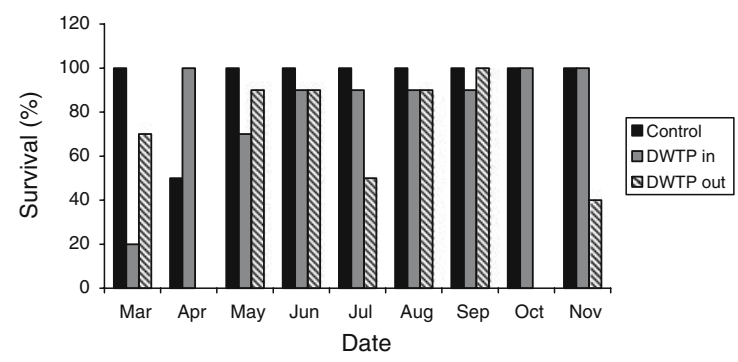

Fig. 4 Survival (\%) of Ceriodaphnia silvestrii in the 10 days chronic toxicity test with water samples from Fonte DWTP (Araraquara city, SP, Brazil). Samples were collected monthly from March to November 2001. (DWTP in = water incoming the treatment plant and DWTP out $=$ water exiting the treatment plant)

The online version of the original article can be found at http:// dx.doi.org/10.1007/s10646-005-0048-y

R. A. Takenaka $\cdot$ O. Rocha

Department of Hydraulic and Sanitation, Engineering School of São Carlos, University of São Paulo, Avenida Trabalhador São Carlense, 400, CEP, 13566-590 São Carlos, SP, Brazil

R. B. Sotero-Santos $(\bowtie) \cdot$ O. Rocha

Department of Ecology and Evolutionary Biology, Biological and Health Sciences Center, Federal University of São Carlos, Rodovia Washington Luis, km 235, CEP, 13565-905 São Carlos, SP, Brazil

e-mail:rmabarb@yahoo.com.br 